HID 48 (2021)

\title{
LA JURISDICCIÓN ESPECIAL DE LAS COMISIONES MILITARES EJECUTIVAS Y PERMANENTES EN LAS POSTRIMERÍAS DEL ANTIGUO RÉGIMEN ${ }^{1}$
}

\author{
THE SPECIAL JURISDICTION OF THE PERMANENT EXECUTIVE \\ AND PERMANENT MILITARY COMMISSIONS \\ IN THE POST-DIMMING OF THE ANCIENT REGIME
}

\author{
Miguel Pino ABAD \\ Universidad de Córdoba \\ miguel.pino@uco.es ORCID: https://orcid.org/0000-0003-3122-1714
}

RESUMEN: Al comienzo de la última fase de su reinado, Fernando VII tomó la determinación de adjudicar a la jurisdicción castrense el conocimiento de las causas seguidas contra quienes fueran considerados contrarios a su persona o gobierno. A eso se sumaron todos los delitos cometidos por quienes perturbaban la tranquilidad pública como ladrones, salteadores de caminos o contrabandistas. Esta situación duró poco más de año y medio, pues en agosto de 1825 quedaron disueltas las llamadas comisiones militares ejecutivas y permanentes, pasando todas las causas que aún estaban pendientes de fallo a la jurisdicción ordinaria, aunque en marzo de 1831 nuevamente fueron restablecidas para reprimir ciertas conductas criminales de especial gravedad acaecidas en las fechas previas. Finalmente, tras la muerte del monarca y la apertura de un nuevo período, estas comisiones dejaron de funcionar.

PALABRAS ClAVE: Jurisdicción castrense; comisión militar; Fernando VII.

ABSTRACT: At the beginning of the last phase of his reign, Fernando VII made the determination to assign to the military jurisdiction the knowledge of the cases followed against those who were considered contrary to his person or government. To this were added all the crimes committed by those who disturbed the

Recibido: 7-5-2020; Aceptado: 14-12-2020; Versión definitiva: 19-12-2020.

1. Este trabajo de investigación pertenece al proyecto titulado "Conflicto y reparación en la historia jurídica española moderna y contemporánea”, referencia PID2020-113346GB-C22, financiado por el Ministerio de Ciencia e Innovación del Gobierno de España en el marco del Programa Estatal de Generación de Conocimiento y Fortalecimiento Científico y Tecnológico del Sistema de I+D+i del Plan de Investigación Científica y Técnica y de Innovación 2017-2020.

Copyright: (C) Editorial Universidad de Sevilla. Este es un artículo de acceso abierto distribuido bajo los términos de la licencia de uso y distribución Creative Commons Reconocimiento-NoComercialSinObraDerivada 4.0 (CC BY-NC-ND 4.0) 
public tranquility such as thieves, highway robbers or smugglers. This situation lasted a little over a year and a half, since in August 1825 the so-called executive and permanent military commissions were dissolved, passing all the cases that were still pending a decision to the ordinary jurisdiction, although in March 1831 they were reinstated again to repress certain particularly serious criminal conduct that occurred on the previous dates. Finally, after the death of the monarch and the opening of a new period, these commissions stopped working.

KEYWORDS: Military jurisdiction; military commission; Fernando VII.

Tras seis años de cautiverio, en 1814 se produjo el retorno de Fernando VII a España, lo que conllevó la restauración del anterior sistema político absolutista. De forma que el programa que pretendió instaurar pasó por la reimplantación de la forma de gobierno y la estratificación social ya conocida antes de la invasión napoleónica ${ }^{2}$.

Esa proyección restauradora o contrarrevolucionaria de la monarquía fernandina explica que se empleara un amplio elenco de medidas contra los partidarios de las ideas liberales, dada su condición de potenciales elementos subversivos. Durante los siguientes años muchos españoles estuvieron inmersos en un clima de auténtico terror. Los gobernantes, obsesionados con borrar todas las reformas emprendidas, estimaron que sólo cabía una solución: el uso de la violencia contra quienes defendían unos postulados diferentes de los oficiales. Sólo a través de esa persecución podemos comprender, por ejemplo, como aconteció el resurgimiento de una institución casi olvidada como fue la Inquisición ${ }^{3}$.

La puesta en práctica de estas radicales medidas no tardó en producirse. En los meses que siguieron al retorno del monarca se acometió un profundo desmantelamiento del partido liberal. Para ello se ordenó el ingreso en prisión de todos sus dirigentes políticos, acusados de usurpar al monarca su soberanía absoluta. Acusación que, curiosamente, no se encontraba apoyada en ningún soporte jurídico, ya que en la legislación vigente por esas fechas no se contemplaba que el simple hecho de defender los principios liberales fuese considerado delito.

Esa falta de tipicidad provocó que los procesos penales que se incoaron contra los liberales se encontraran plagados de irregularidades, comenzando por el hecho de que no se sabía a qué jueces competía su conocimiento ${ }^{4}$. Ello determinó que unas veces se atribuyese a los jueces de policía, otras a los alcaldes de casa

2. Herr 1977 , p. 108.

3. Artola 1981, p. 44 abordó con detalle esta materia, donde subraya el fin destructor de las decisiones adoptadas por el monarca tras su vuelta. Según advierte, "sólo se salvaron de esta radical revisión dos instituciones: la Junta de crédito público y el decreto de las Cortes que abolió el tormento, confirmado por real cédula de 25 de julio".

4. Fiestas Loza 1994, p. 70. Falta de garantías de los derechos de los españoles que también habían existido durante el período constitucional, tal y como señalan Garriga y Lorente 1998, p. 612: "Por más que se dijera, la garantía de los derechos no estaba ni en la ley ni en la inexistente jurisprudencia (escrita) de los jueces, sino en la actitud constitucional de todas y cada una de las autoridades políticas, entendiendo por tal el mero reconocimiento de la soberanía de las Cortes ... La regulación de la responsabilidad de los empleados públicos, comprendidos los jueces, se desvinculó 
y corte e, incluso, a comisiones integradas por militares, políticos y jueces. Todo esto provocó la imposición de condenas arbitrarias contra un ingente número de inocentes ${ }^{5}$, a quienes se trató como traidores ${ }^{6}$ y que fueron encarcelados o forzados a exiliarse ${ }^{7}$.

Represión personal a la que acompañó la sistemática supresión de todos los órganos de gobierno, justicia y legislativos establecidos por los constitucionalistas y a su sustitución por los que ya existían antes de 1808, mediante la promulgación del conocido decreto de 4 de mayo de $1814^{8}$. Se abolieron las Cortes, la Regencia, las Diputaciones provinciales, los Ayuntamientos constituidos según los criterios marcados por la Constitución, etc. En su lugar, se reimplantaron las carteras ministeriales o secretarías al estilo propio del pasado; los capitanes generales sumaron a su poder militar el gubernativo; las Audiencias y Chancillerías se atribuyeron también cometidos de gobierno junto a los estrictamente judiciales; en los municipios se restauraron los antiguos cargos de corregidores y alcaldes mayores, con sus competencias típicas de períodos pretéritos ${ }^{9}$. Y, en el aspecto que más nos interesa en estas líneas, se renovó la vigencia de la legislación penal inserta en las Partidas, la Novísima Recopilación y en otras disposiciones dictadas desde el siglo XIII ${ }^{10}$.

Después del paréntesis que supuso el Trienio Liberal, la vuelta al absolutismo en 1823 provocó un recrudecimiento de la política represora de Fernando VII ${ }^{11}$. En ese contexto se explica la creación de las llamadas comisiones militares ejecutivas y permanentes en todas las capitales de provincia para castigar a los que pretendieran actuar contra él ${ }^{12}$, bajo la excusa de la existencia en diferentes localidades de individuos acostumbrados a alterar la tranquilidad pública por proferir expresiones contrarias a la Monarquía y a favor de la abolida Constitución de 1812. A ello se sumaba la existencia cuadrillas armadas en los caminos que perturbaban la seguridad de los mismos, causando daños a quienes se hallaran en ellos. Por eso, se consideró que era imprescindible arbitrar medidas para alcanzar el rápido castigo de los autores de delitos tan graves y nada mejor para ello que adjudicar la competencia a las referidas comisiones en detrimento de la jurisdicción ordinaria.

Esa ampliación competencial de la justicia castrense no fue novedosa. Ya en el último tercio de la centuria anterior los militares estuvieron llamados a desempeñar una importante labor en la persecución y detención de ciertos tipos de delincuentes. Por esa razón, se estimó oportuno ampararlos especialmente cuando

por completo de la construcción del régimen de legalidad, o mejor, ésta se sustituyó durante años por aquélla".

5. Artola 1978 , p. 187.

6. Herr 1977, p. 109.

7. Carr 1984, p. 133.

8. Las consecuencias que trajo aparejadas la entrada en vigor de este decreto pueden consultarse en Fiestas Loza 1994, p. 67 y ss.

9. Artola 1978 , pp. 188 a 190.

10. Ortego Gil 2015, p. 47.

11. Peset Reig 1967, p. 438.

12. Como recordaba Mariana 1840, tomo X, p. 110, los primeros actos de la restauración de Fernando VII fueron, junto a la creación de las comisiones militares y ejecutivas, la reposición a su antiguo estado de las comunidades religiosas y la purificación de todos los empleados. 
eran objeto de ataques por los malhechores. Así, Carlos III, mediante real decreto de 2 de abril, inserto en cédula del Consejo de 5 de mayo de 1783, declaró que los bandidos, contrabandistas o salteadores de caminos que hiciesen fuego o resistencia con arma blanca a la tropa, que los capitanes o comandantes generales emplearen, destinados expresamente al objeto de perseguirlos por sí o como ayudantes de las jurisdicciones reales ordinaria o de rentas, quedaban sujetos a la jurisdicción militar para ser juzgados por un consejo de guerra de oficiales, presidido por el que eligiera el capitán o comandante general de la provincia donde se hubiese producido la resistencia. Los delincuentes, en quienes no se acreditase que habían disparado o practicado resistencia con arma blanca, pero que concurrieron con los que sí, eran sentenciados por el propio consejo de guerra a diez años de presidio, ejecutándose sin dilación estas sentencias ${ }^{13}$.

Al año siguiente, el monarca, por instrucción de 29 de junio de 1784, manifestó que para que se administrase pronto justicia contra los bandidos y contrabandistas, se informase al capitán o comandante general de la provincia del arresto y sus circunstancias, para que, en el caso de que hubiese mediado resistencia a la tropa, mandase formar proceso y sentenciarlos por el consejo de guerra de oficiales. Pero si no hubiese ocurrido resistencia a la tropa, dispondría que, sin la menor dilación, se entregasen los reos y lo que se les hubiese aprehendido a la justicia real ordinaria, en caso de que fueran ladrones y malhechores sujetos a su jurisdicción o al Juzgado de Rentas de la provincia, si fueren defraudadores de ellas, encargando a estos tribunales que procurasen evacuar cuanto antes sus causas para el más pronto y debido castigo, a cuyo fin el capitán o comandante general había de facilitar los testigos y declaraciones que necesitasen de los militares que se hubiesen hallado en la prisión, dando aviso por la Secretaría del Despacho Universal de la Guerra de los casos en que notare dilaciones, negligencias u omisiones en los procesos y castigos ${ }^{14}$. Medidas que fueron ratificadas en los albores de la siguiente centuria a través de las reales órdenes de 30 de marzo de 1801 y 10 de abril de 1802 para contener y castigar los escandalosos delitos que se cometían por multitud de malhechores, de forma que aquellos reos que fuesen atrapados por las partidas de tropa comisionadas para ello debían ser juzgados en consejo de guerra ordinario de oficiales ${ }^{15}$.

\section{PRIMERA FASE: DEL 13 DE ENERO DE 1824}

\section{AL 4 DE AGOSTO DE 1825}

Como hemos apuntado, el éxito cosechado por la jurisdicción castrense durante las décadas anteriores en el castigo de ciertos tipos de delitos debió ser la razón que justificó que, en cumplimiento de la real orden de 13 de enero de 1824

13. Novísima Recopilación XII,10,10.

14. Novísima Recopilación XII,17,5, cap. 9.

15. Novísima Recopilación, XII, 17,8. 
del ministro de la Guerra, general José de la Cruz, se establecieran en todas las capitales de provincia, incluidas las Islas Baleares, en el término de quince días desde la publicación de la norma, las referidas comisiones militares ejecutivas y permanentes, compuestas por un presidente de la clase de brigadier, seis vocales de la de coroneles hasta sargento mayor inclusive y un asesor, elegidos los primeros entre los que por su lealtad al monarca merecieran la confianza de los capitanes generales. También contarían con cuatro fiscales e igual número de secretarios para que formasen las causas a los reos de los delitos perpetrados desde el 1 de octubre de $1823^{16}$. En particular, quedarían sujetos a su jurisdicción quienes hubiesen escrito papeles o pasquines dirigidos a atacar los derechos del rey; los que en los lugares públicos hubieran hablado contra la soberanía real o a favor de la Constitución; los que sedujeran a otros con el objeto de formar cuadrillas; los promotores de alborotos que alterasen la tranquilidad pública, con independencia de cuáles fueran sus causas y los malhechores que en los caminos fuesen aprehendidos por cualquier tropa o voluntarios realistas.

En la propia orden se hizo hincapié en el dato de que las causas se debían sustanciar en el término más corto posible, bajo la responsabilidad, en caso contrario, del presidente, vocales y fiscal. Las dudas que pudieran surgir en la sustanciación se habían de resolver por el asesor de la comisión, a quien acudían los fiscales por conducto de los presidentes. Conforme a esto, si eran muchos los reos aprehendidos por un mismo delito, se formaban ramos separados, previo dictamen del asesor, para abreviar de este modo la sustanciación y el pronto castigo o libertad de los acusados.

Finalizadas las causas, se entregaban al presidente de la comisión para que las pasase al asesor y dijese éste si tenían o no algún defecto. En caso afirmativo, se corregía y, en el negativo, se entregaban a los defensores por el término que pareciera bastante al presidente, el cual concedía una prórroga que no pasase de tres días, examinando después de pronunciar el fallo, si dicha solicitud fue o no necesaria, imponiendo al defensor, en caso contrario, la pena correccional que estimase oportuna. Los asesores no tenían voto para el fallo, con arreglo a lo establecido para los procesos militares, pero ilustraban a los vocales antes de la votación. Cuando la sentencia que recaía no estaba arreglada a la opinión del asesor, lo ponía éste por escrito y se unía a la causa.

Pronunciada la sentencia, se remitía con el proceso al capitán general de la provincia, quien la pasaba al auditor de guerra para que la examinase. Si de esta revista resultaba arreglada, el capitán general disponía que se ejecutase sin dilación, pero si el auditor encontraba motivo fundado que ofreciera duda o exigiera consulta, el capitán general nombraba, como presidente de la Audiencia territorial, tres ministros de ella, con cuyo dictamen decidía o consultaba al Consejo Supremo de Guerra, extendiendo con claridad los fundamentos de la duda o consulta. En el

16. Es bien sabido que ese día, Fernando VII firmaba en el Puerto de Santa María el decreto por el que declaraba nulos y sin valor todos los actos del Gobierno constitucional. Gaceta de Madrid, 7 de octubre de 1823. Sobre la real orden de creación de las comisiones militares puede verse Ballbé 1983 , p. 89. 
caso concreto del territorio de Castilla la Nueva, el capitán general pasaba oficio al gobernador del Consejo para que, nombrados por éste tres ministros de la Sala de Alcaldes de Casa y Corte, decidiera, con el dictamen de éstos, los procesos que ofrecían duda o consulta.

Conviene subrayar que quienes incurrían en los delitos de que debían conocer las comisiones militares ejecutivas y permanentes quedaban automáticamente desaforados, con independencia de cual fuese su clase, grado, estado o condición, por lo que dejaban de tener aplicación todas las órdenes, leyes y reales cédulas, en cuanto se opusieran a ésta de 13 de enero de 1824, salvo que el reo fuera eclesiástico, para quien debería tenerse en consideración lo previsto en la real orden de 13 de septiembre de 1814 , que quedaba vigente ${ }^{17}$.

Otro aspecto también destacable es que la disposición por la que se crearon las comisiones no tenía efecto retroactivo, lo que conllevó que los jueces ordinarios continuaran conociendo de las causas que hubiesen incoado sobre los mismos delitos, con la advertencia de que debían sustanciarlas y determinarlas a la mayor brevedad, según las leyes. Pero, desde el momento del establecimiento de las comisiones militares, si los oficiales de justicia aprehendían algunos reos de dichos crímenes debían entregarlos a los presidentes de las comisiones con la sumaria que hubiesen formado sobre el hecho, practicándose lo mismo con los detenidos por la policía.

Desde un principio, se pretendió dejar claro que la jurisdicción de las comisiones era especial y, por tanto, quedaba circunscrita a los delitos indicados, de forma que no podían proceder contra los malhechores que no fuesen de dichas clases ni sus cómplices, ya que ellos quedarían sujetos a los jueces a quienes correspondiera el conocimiento de sus causas. En caso de que se planteara duda sobre si el conocimiento de alguna causa correspondía a la comisión militar o a otra jurisdicción, se debía remitir en el estado en que se hallaba al capitán general y que éste la pasase a un oidor y al auditor de guerra para que decidieran. Si había discordia entre ellos, se nombraba otros tres oidores para que viesen la causa y la determinasen.

Los capitanes generales debían informar, para la aprobación real, a quienes proponían para ser presidente, vocales y asesor de dichas comisiones militares y del día en que se iban a constituir. Además, habían de hacerlo sobre la conducta que observasen sus miembros una vez se encontrasen funcionando y cada quince días del número de causas formadas, estado de ellas y los fallos pronunciados y ejecutados ${ }^{18}$.

17. Para comprender esa excepción a la regla general no hay que perder de vista que durante esos años cristalizó una nueva alianza entre el trono y el altar. Como recuerda Revuelta González 1973, p. 3 "la Iglesia española no sólo se consideraba víctima de régimen napoleónico, sino también del régimen nacional instaurado por los liberales de Cádiz...La restauración del Antiguo Régimen se hará, por tanto, bajo el lema del trono y el altar, en un movimiento de apoyo mutuo. La Iglesia necesitaba un apoyo especial para restañar las heridas recibidas. Era, pues, obligación de Fernando mostrar su agradecimiento a la Iglesia que había contribuido con sus aportaciones económicas, con sus exhortaciones y con sus plegarias a su feliz retorno".

18. Real orden de 13 de enero de 1824; Diario Mercantil de Cádiz, no 2735 de 24 de enero de 1824 , p. 2 a 4 y n 2737 de 26 de enero de 1824, p. 2 y 3; Diario balear, $\mathrm{n}^{\circ} 38$ de 7 de febrero de 
Una de las primeras comisiones en constituirse fue la de Castilla la Nueva, como medida para frenar el sinfín de robos que se venían cometiendo en la Corte, tanto en las calles como en casas particulares ${ }^{19}$, aunque a las pocas semanas el presidente advirtió de los atrasos que sufrían las causas de que conocía dicha comisión por las dilaciones que resultaban de las comparecencias de los testigos y peritos que tenían que declarar. El hecho de estar sujetos a otras jurisdicciones obligaba a los fiscales a solicitar a sus jueces naturales para que concedieran el preceptivo permiso por lo que era imposible lograr la brevedad que se reclamaba en la tramitación de estas causas. Por ello se dispuso que, todo individuo que debía declarar ante la comisión militar de la corte, lo llevase a cabo, sin necesidad de autorización de la autoridad de quien dependiera. Medida que se hizo extensiva a las otras comisiones militares ya establecidas o que se crearan más adelante ${ }^{20}$.

Otra duda planteada por el presidente de la comisión de la Corte fue si los fiscales de ella estaban o no autorizados para proceder a los embargos de bienes de los reos sujetos a su jurisdicción y si correspondía verificar dicha diligencia al alguacil mayor o, en su defecto, al segundo de la capitanía general. Ante esa cuestión, se resolvió el 30 de marzo de 1824 que los fiscales de las comisiones militares ejecutivas estaban autorizados para proceder al embargo de bienes de los acusados de cuyos delitos conocían en todos aquellos casos en que podía haber lugar a los mismos. En el supuesto de que carecieran aquéllas de alguaciles y de otros dependientes para verificarlos, debían valerse de los juzgados militares siempre que los hubiera en las localidades donde residieran las comisiones, que, en caso contrario, autorizarían a las personas que fuesen de su confianza para que los practicasen, nombrando siempre depositarios para la conservación y custodia de los efectos embargados ${ }^{21}$.

Salvados esos iniciales escollos, la comisión de Castilla la Nueva empezó a funcionar sin mayor dificultad. Uno de los primeros procesos incoados tuvo como protagonista a un tal Diego Pérez de 56 años de edad y oficio hortelano, quien, según parece, al salir del Paseo del Retiro la tarde del 25 de enero de 1824, cuando un batallón de la guardia real suiza se hallaba formado para la lista, exclamó: Vengan ahora los que querían matar a S. M. y muera el rey la religión. Estas últimas palabras de muera el rey y la religión las oyó un comisario, que no habiendo percibido las primeras, calificó a Pérez de sedicioso y le condujo arrestado. El acusado refirió en su declaración que muera el rey y la religión era relativo al vengan ahora los querían matar a $S$. M. . Tras ser preguntados cuatro testigos y recibir el informe

1824, pp. 1 a 3. Recientemente se ha referido escuetamente a la creación de estas comisiones Barroso González, 2014, p. 5.

19. Real orden de 18 de enero de 1824 sobre instalación en esta Corte de la comisión militar ejecutiva y permanente en Gaceta de Madrid, $\mathrm{n}^{\circ} 11$ de 24 de enero de 1824, pp. 45 y 46 . Las penas que debían aplicarse a los delincuentes aparecen recogidas en Novísima Recopilación XII, 14, leyes 3 y 5 y en el artículo $2^{\circ}$ de la real orden de 31 de agosto de 1772.

20. Real orden de 26 de febrero de 1824, Diario Mercantil de Cádiz, nº 2783 de 12 de marzo de 1824 , p. 2; Diario balear, ${ }^{\circ} 85$ de 25 de marzo de 1824 , p. 1.

21. Bacardi, 1848, tomo I, p. 241. 
de su alcalde de barrio, donde se definió al acusado como un vecino laborioso y enemigo de la Constitución y que siempre gritaba en público a favor del soberano, por lo que las gentes de su barrio lo conocían como el predicador, la comisión, unánimemente, declaró inocente a Diego Pérez el 8 de febrero, poniéndolo en libertad, aunque apercibiéndole de abstenerse en lo sucesivo de gritar en público.

Peor suerte corrieron Andrés Ruiz y Francisco Fernández, de 27 y 22 años y naturales de Coria del Río y Madrid, respectivamente, que fueron sentenciados a pena de muerte el 20 de febrero, la cual se ejecutó el 26 del mismo mes. Según consta, los dos condenados, junto con otro compañero, entraron el día 27 de enero a las cuatro de la tarde en el cuarto bajo de la casa número 3 de la calle Tentetieso y se llevaron cuanto encontraron de la inquilina, que era lavandera. Avisada la guardia de voluntarios realistas de la villa, se presentó una patrulla hacia la calle de la Almudena y divisó a tres hombres que corrían por la calle que había entre los Consejos y monjas del Sacramento, quienes, para correr mejor, arrojaron un talego de ropa sucia y otros objetos. Después de ser puestos los acusados en rueda de presos, quedó justificado para la comisión que habían sido los autores de un robo en cuadrilla. Conforme a ello, falló condenarles a muerte ${ }^{22}$.

En ese mismo mes de marzo se dictó sentencia contra Manuel Estévez, casado, natural de Manises, de 27 años de edad, quien en unión con otro vestido de militar, asaltó a un individuo que se retiraba a su casa sobre las ocho y media de la noche del 10 de febrero, cogiéndolo del cuello para exigirle el reloj y el dinero que portaba. Se apropiaron de dos pesetas, once cuartos y una navaja de Albacete que llevaba en el bolsillo. El reo fue aprehendido por una patrulla, aunque consiguió escapar su cómplice, y sentenciado el día 1 a la pena de horca, que se ejecutó tres días después ${ }^{23}$. También hallamos el proceso contra Carlos López y Francisco Flores, naturales de Madrid, de 22 y 26 años de edad, criados de la fonda de San Fernando, quienes, hallándose dentro de un cuarto de la calle de Chincilla a las nueva y media de la noche del 30 de enero, entonaron canciones cuya letra no pudo percibir la patrulla realista que los apresó y sí solo un estribillo de muera el Baron de Eroles y viva la libertad. Justificado el hecho, fallada la causa por la comisión, no conformándose el auditor y remitido el proceso a la Sala de Alcaldes de Casa y Corte, fueron sentenciados a seis años de presidio, no habiéndose aprobado los doscientos azotes que les adicionó la comisión militar.

Junto a las referidas, entre otras causas ${ }^{24}$ seguidas durante esos meses ante la comisión de Castilla la Nueva se encontraron las siguientes ${ }^{25}$ :

22. Gaceta de Madrid, no 29 de 4 de marzo de 1824, pp. 123 y 124; Diario balear, no 86 de 26 de marzo de 1824 , pp. 3 y 4.

23. Diario balear, $\mathrm{n}^{\circ} 89$ de 29 de marzo de 1824, p. 3.

24. Al objeto de ofrecer al lector una visión de conjunto sobre la identidad, delitos acusados y contenido de las sentencias dictadas contra los respectivos procesados, se ofrecen los datos de forma esquemática en esta tabla. De la misma forma, procederemos más adelante cuando nos refiramos tanto a ésta como a otras comisiones militares.

25. Gaceta de Madrid, $\mathrm{n}^{\circ} 38$ de 23 de marzo de 1824, pp. 159 y 160; n 45 de 6 de abril de 1824 , pp. 185 y $186 ; \mathrm{n}^{\circ} 29$ de 8 de marzo de 1825 , pp. 115 y 116. También al respecto Diario balear, $\mathrm{n}^{\circ} 20$ de 20 de abril de 1824 , p. 4. 


\begin{tabular}{|c|c|c|}
\hline Identidad de los procesados & Delitos & Sentencias \\
\hline $\begin{array}{l}\text { Joaquín Montalbán y } \\
\text { Vicente del Campo, } \\
\text { naturales de Madrid, de } 20 \\
\text { y } 23 \text { años }\end{array}$ & $\begin{array}{l}\text { Gritar en las calles de } \\
\text { Madrid Viva Riego, Quiroga } \\
\text { y su ejército }\end{array}$ & $\begin{array}{l}\text { Horca, conmutada por los } \\
\text { alcaldes de casa y corte a } \\
\text { diez años de presidio. }\end{array}$ \\
\hline $\begin{array}{l}\text { Agustín García, natural de } \\
\text { Badajoz, de } 28 \text { años }\end{array}$ & $\begin{array}{l}\text { Salteador de caminos y no } \\
\text { tener ocupación conocida }\end{array}$ & $\begin{array}{l}\text { Cuatro años de presidio en } \\
\text { uno de África }\end{array}$ \\
\hline $\begin{array}{l}\text { Antonio Quintas y José } \\
\text { Majolero, naturales de } \\
\text { Madrid, de } 15 \text { y } 17 \text { años }\end{array}$ & $\begin{array}{l}\text { Conato de robo simple de } \\
\text { una manta }\end{array}$ & $\begin{array}{l}\text { Un mes de encierro en la } \\
\text { cárcel }\end{array}$ \\
\hline $\begin{array}{l}\text { Manuel García, de Asturias, } \\
\text { de } 23 \text { años }\end{array}$ & $\begin{array}{l}\text { Cantar públicamente el } \\
\text { Trágala, mientras estaba } \\
\text { embriagado }\end{array}$ & $\begin{array}{l}\text { Realización de trabajos } \\
\text { públicos en Madrid durante } \\
\text { un año }\end{array}$ \\
\hline Manuel Barrero & $\begin{array}{l}\text { Traidor a los derechos del } \\
\text { rey }\end{array}$ & $\begin{array}{l}\text { Ser pasado por las armas por } \\
\text { la espalda. Se le conmutó } \\
\text { por la de presidio a diez años } \\
\text { en el Peñón de la Gomera y } \\
\text { apercibimiento que, en caso } \\
\text { de reincidencia, sufriría la } \\
\text { pena de muerte. }\end{array}$ \\
\hline Cirilo Becarez & Proferir palabras alarmantes & Un mes de cárcel \\
\hline Cesáreo Vequillas & $\begin{array}{l}\text { Haber cantado el Trágala } \\
\text { constitucional }\end{array}$ & Diez años de presidio \\
\hline $\begin{array}{l}\text { Plácido Martín de Blas, } \\
\text { Lucío González, Saturnino } \\
\text { González, Miguel López, } \\
\text { Pablo Aparicio y Elías } \\
\text { González }\end{array}$ & $\begin{array}{l}\text { Proferir expresiones } \\
\text { subversivas }\end{array}$ & $\begin{array}{l}\text { Diez años de presidio en uno } \\
\text { de los mayores de África }\end{array}$ \\
\hline Alfonso Morcillo & $\begin{array}{l}\text { Robo de diligencia en } \\
\text { despoblado a mano armada } \\
\text { junto a otros individuos }\end{array}$ & Horca \\
\hline $\begin{array}{l}\text { Vicente Oroz y Saturnino } \\
\text { Espinosa }\end{array}$ & $\begin{array}{l}\text { Haber proferido públicamente } \\
\text { las expresiones Muera el } \\
\text { rey, mueran los consejeros } \\
\text { y muera también la reina y } \\
\text { viva Riego }\end{array}$ & $\begin{array}{l}\text { El primero, ser pasado por } \\
\text { las armas. El segundo, diez } \\
\text { años de presidio con } \\
\text { retención por haberse } \\
\text { asociado con aquél en la } \\
\text { comisión de otros delitos. }\end{array}$ \\
\hline
\end{tabular}

En total, las causas falladas o sobreseídas desde la instalación de la comisión de Castilla la Nueva en enero de 1824 y hasta el 8 de febrero de 1825 ascendieron a 109 y 167, respectivamente, lo que demuestra la intensa actividad que desarrolló en poco más de un año ${ }^{26}$.

Desde entonces y hasta mayo de ese año de 1825, la comisión que analizamos conoció de las causas siguientes:

26. Gaceta de Madrid, $\mathrm{n}^{\circ} 30$ de 10 de marzo de 1825, p. 119; $\mathrm{n}^{\circ} 55$ de 7 de mayo de 1825, p. 220 . 


\begin{tabular}{|c|c|c|}
\hline Identidad de los procesados & Delitos & Sentencias \\
\hline Benito Azcorbe, de Madrid & Robo & $\begin{array}{l}\text { Ocho años en el presidio de } \\
\text { Alhucemas }\end{array}$ \\
\hline $\begin{array}{l}\text { Manuel Cándido Ortiz, de la } \\
\text { Puebla de Don Fadrique }\end{array}$ & $\begin{array}{l}\text { Proferir palabras contra el } \\
\text { Gobierno }\end{array}$ & $\begin{array}{l}\text { Un mes de cárcel que se } \\
\text { sumaba al tiempo que } \\
\text { llevaba en prisión preventiva }\end{array}$ \\
\hline $\begin{array}{l}\text { Joaquín Méndez, José } \\
\text { Saturnino Esteban, Juana } \\
\text { Álvarez, María González, } \\
\text { Antonio Monsalve y } \\
\text { Severiana Mora }\end{array}$ & $\begin{array}{l}\text { El primero, por proferir } \\
\text { palabras subversivas. } \\
\text { El segundo, la tercera y } \\
\text { cuarta, por complicidad y } \\
\text { encubrimiento de aquél. } \\
\text { El quinto, no se encontró } \\
\text { culpable. Sí Severiana, mujer } \\
\text { de Méndez }\end{array}$ & $\begin{array}{l}\text { Méndez, pena ordinaria de } \\
\text { horca y confiscación de } \\
\text { todos sus bienes. Esteban, } \\
\text { seis años en el presidio de } \\
\text { Ceuta. Álvarez y González, } \\
\text { seis meses de galera. } \\
\text { Monsalve, libertad. Mora, } \\
\text { tres meses de prisión que } \\
\text { se sumaba al tiempo que } \\
\text { llevaba. }\end{array}$ \\
\hline Gregorio Calvo, de Madrid & Robo & $\begin{array}{l}\text { Seis meses en el correccional } \\
\text { de la Corte }\end{array}$ \\
\hline $\begin{array}{l}\text { María José López, } \\
\text { de Madrid }\end{array}$ & $\begin{array}{l}\text { Robar una capa y ser } \\
\text { encubridora de ladrones }\end{array}$ & Diez años de galera \\
\hline $\begin{array}{l}\text { Justo Serrano y Antonio } \\
\text { Vega, de Madrid }\end{array}$ & $\begin{array}{l}\text { El primero por proferir } \\
\text { expresiones subversivas y el } \\
\text { segundo de perjuro }\end{array}$ & $\begin{array}{l}\text { El primero, a no residir en la } \\
\text { Corte ni en quince leguas de } \\
\text { distancia. El segundo, a la } \\
\text { pena de prisión que llevaba. }\end{array}$ \\
\hline Francisco González & $\begin{array}{l}\text { Robo con reincidencia y } \\
\text { asociación con individuos } \\
\text { sospechosos }\end{array}$ & $\begin{array}{l}\text { Diez años en el presidio de } \\
\text { Melilla }\end{array}$ \\
\hline $\begin{array}{l}\text { Pedro Pablo Gallardo, } \\
\text { de Almagro }\end{array}$ & $\begin{array}{l}\text { Proferir expresiones } \\
\text { subversivas }\end{array}$ & $\begin{array}{l}\text { Absuelto y puesto en } \\
\text { libertad, quedando } \\
\text { apercibido bajo la vigilancia } \\
\text { de la justicia }\end{array}$ \\
\hline Teresa Ramírez, de Madrid & $\begin{array}{l}\text { Proferir expresiones } \\
\text { subversivas }\end{array}$ & $\begin{array}{l}\text { Seis meses de galera por } \\
\text { tener ideas contrarias al } \\
\text { Gobierno }\end{array}$ \\
\hline Josefa López, de Madrid & $\begin{array}{l}\text { Proferir expresiones } \\
\text { subversivas }\end{array}$ & Cuatro años de galera \\
\hline $\begin{array}{l}\text { Mariano Peiroteo, } \\
\text { de Madrid. Carpintero }\end{array}$ & $\begin{array}{l}\text { Tener una mesa con un } \\
\text { letrero subversivo }\end{array}$ & $\begin{array}{l}\text { Prisión que llevaba y } \\
\text { destrucción de la mesa }\end{array}$ \\
\hline $\begin{array}{l}\text { Francisco Molins, } \\
\text { de Moncada }\end{array}$ & $\begin{array}{l}\text { Robo y uso de armas } \\
\text { prohibidas }\end{array}$ & $\begin{array}{l}\text { Ocho años de presidio en el } \\
\text { de Ceuta }\end{array}$ \\
\hline $\begin{array}{l}\text { Juan Antonio Rodríguez, de } \\
\text { Coruña }\end{array}$ & Robo de dos duros & $\begin{array}{l}\text { Horca, conmutada por la de } \\
\text { cuatro años de presidio }\end{array}$ \\
\hline
\end{tabular}




\begin{tabular}{|c|c|c|}
\hline Identidad de los procesados & Delitos & Sentencias \\
\hline $\begin{array}{l}\text { Marcelino Ramiro, Vicente } \\
\text { Rosillo, Vicente Tomillo, } \\
\text { José Cayuela y Pascual } \\
\text { Moratalla. Los tres primeros } \\
\text { de Provencio. El cuarto de } \\
\text { Lebrilla y el quinto de La } \\
\text { Alberca }\end{array}$ & Robo con reincidencia & $\begin{array}{l}\text { Ramiro, como cabecilla, } \\
\text { horca. Cayuela, Moratalla } \\
\text { y Rosillo, doscientos azotes } \\
\text { y diez años de presidio en } \\
\text { el de Melilla. Tomillo, por } \\
\text { juntarse con los anteriores, } \\
\text { cuatro años de presidio en el } \\
\text { de Ceuta }\end{array}$ \\
\hline $\begin{array}{l}\text { Isidoro Pintado y Gabriel } \\
\text { Sarabia. El primero de Arges } \\
\text { y el segundo de Cuéllar de } \\
\text { Baza }\end{array}$ & Posesión de ganzúas & $\begin{array}{l}\text { Pintado, dos años en el } \\
\text { correccional de El Prado. } \\
\text { Sarabia quedó en libertad, } \\
\text { sirviendo la pena de prisión } \\
\text { que llevaba. }\end{array}$ \\
\hline José González, de Sevilla & $\begin{array}{l}\text { Reunirse con ladrones y } \\
\text { tener una canana con } \\
\text { cartuchos }\end{array}$ & $\begin{array}{l}\text { Diez años de presidio en uno } \\
\text { de los de África }\end{array}$ \\
\hline $\begin{array}{l}\text { Tiburcio Prieto, } \\
\text { de Palomares del Campo }\end{array}$ & Proferir palabras subversivas & $\begin{array}{l}\text { Dos años en el correccional } \\
\text { de El Prado }\end{array}$ \\
\hline $\begin{array}{l}\text { Miguel Pardo y Nicolás } \\
\text { Herrero, de Utiel }\end{array}$ & Robo & $\begin{array}{l}\text { Pardo, doscientos azotes y } \\
\text { diez años de presidio en el de } \\
\text { Ceuta. Herrero, ocho años de } \\
\text { presidio en el de Melilla. }\end{array}$ \\
\hline Polonia Benito, de Madrid & Robo de ropa en la Corte & $\begin{array}{l}\text { Garrote, conmutado por tres } \\
\text { años de reclusión. }\end{array}$ \\
\hline $\begin{array}{l}\text { Juan Federico Menaje, } \\
\text { teniente de infantería, } \\
\text { procedente del ejército } \\
\text { revolucionario }\end{array}$ & $\begin{array}{l}\text { Intentar envenenar las aguas } \\
\text { de la fuente del Berro, } \\
\text { destinadas al uso y bebida de } \\
\text { la familia real }\end{array}$ & Horca \\
\hline $\begin{array}{l}\text { Francisco Sanz, } \\
\text { alias Cantina }\end{array}$ & Robo de un caballo & Horca \\
\hline Manuel Franco, de Madrid & Robo de 4641 reales & Horca \\
\hline $\begin{array}{l}\text { Alfonso Montalvo, } \\
\text { de Valdepeñas, abogado de } \\
\text { profesión }\end{array}$ & Conspiración & $\begin{array}{l}\text { Seis años de presidio en el } \\
\text { de Alhucemas. Su padre fue } \\
\text { condenado a un año en el } \\
\text { correccional de la Corte y su } \\
\text { madre a reclusión durante } \\
\text { seis meses }\end{array}$ \\
\hline $\begin{array}{l}\text { Miguel Parrilla, } \\
\text { de Zaragoza. Liberal } \\
\text { exaltado }\end{array}$ & $\begin{array}{l}\text { Pertenencia a una partida que } \\
\text { perseguía realistas }\end{array}$ & $\begin{array}{l}\text { Diez años de presidio en el } \\
\text { de Ceuta }\end{array}$ \\
\hline Restituto Navarro & $\begin{array}{l}\text { Robo en despoblado con uso } \\
\text { de armas prohibidas }\end{array}$ & $\begin{array}{l}\text { Cuatro años de presidio en el } \\
\text { de Málaga }\end{array}$ \\
\hline Leandro Lorca & Proferir palabras subversivas & $\begin{array}{l}\text { Un año en el correccional de } \\
\text { la Corte }\end{array}$ \\
\hline
\end{tabular}


Además de las causas que hemos referido, fueron sobreseídas en sumario sesenta y cinco, por ser su formación dimanada de delitos de corta entidad ${ }^{27}$.

Finalmente, desde mayo hasta la disolución de la comisión en agosto de 1825, ésta falló las siguientes causas:

\begin{tabular}{|c|c|c|}
\hline Nombres de los procesados & Delitos & Sentencias \\
\hline $\begin{array}{l}\text { Francisco Simarro, Juan } \\
\text { Ramón Gascón, Julián Lucas } \\
\text { Guijarro }\end{array}$ & $\begin{array}{l}\text { Haber disparado a una ronda } \\
\text { de voluntarios realistas }\end{array}$ & $\begin{array}{l}\text { Fueron absueltos los dos } \\
\text { primeros, bastando el tiempo } \\
\text { de prisión de llevaban. } \\
\text { Mientras que Guijarro fue } \\
\text { condenado a seis meses de } \\
\text { prisión }\end{array}$ \\
\hline Martín Cuevas & $\begin{array}{l}\text { Tener ideas contrarias al } \\
\text { Gobierno del rey y provocar } \\
\text { una riña en su pueblo }\end{array}$ & $\begin{array}{l}\text { Quince días de cárcel que se } \\
\text { sumaba a la que llevaba }\end{array}$ \\
\hline $\begin{array}{l}\text { Juan Caballero de Gracia, } \\
\text { José González, José Toledo, } \\
\text { Ginés Sánchez, Tomás Diaz, } \\
\text { Manuel Quesada, Manuel } \\
\text { Iliosa, Pedro Vilgos, } \\
\text { Francisco Mazorla, vecinos } \\
\text { todos de Madrid }\end{array}$ & $\begin{array}{l}\text { Robo en cuadrilla, resistencia } \\
\text { y disparar a los voluntarios } \\
\text { realistas de Robledillo }\end{array}$ & $\begin{array}{l}\text { El primero, garrote. Los siete } \\
\text { siguientes a la ordinaria de } \\
\text { horca y el último, por no } \\
\text { haber hecho resistencia, a la } \\
\text { de ocho años de presidio. }\end{array}$ \\
\hline $\begin{array}{l}\text { Francisco Cepeda, } \\
\text { de Tomelloso }\end{array}$ & $\begin{array}{l}\text { Proferir una expresión } \\
\text { temeraria y escandalosa } \\
\text { contra el rey }\end{array}$ & $\begin{array}{l}\text { No resultó probado el delito } \\
\text { y sí que se trató de una } \\
\text { calumnia de Francisco Sales } \\
\text { Carretero, comandante de } \\
\text { realistas de la villa de } \\
\text { Malagón. Este fue } \\
\text { condenado al pago de } 80 \\
\text { reales diarios al procesado } \\
\text { desde que fue preso hasta su } \\
\text { puesta en libertad, privación } \\
\text { del empleo de comandante y } \\
\text { cuatro años de presidio. }\end{array}$ \\
\hline
\end{tabular}

Junto a estas causas, quedaron sobreseídas dieciséis, siendo los acusados en ellas castigados a penas correccionales o absueltos cuando no resultaba cargos contra ellos ${ }^{28}$.

Con similar severidad actuaron las comisiones de otros territorios. Empezamos por la de Aragón que, desde su constitución hasta el 14 de abril de 1824, procesó y sentenció, entre otros, a los siguientes individuos: Carlos Garbayo, Evaristo Ochoa, José María Elizondo, Mariano Joben e Isidro Hernández. El primero era paisano y los cuatro restantes militares del batallón de voluntarios de Aragón,

27. Gaceta de Madrid, $\mathrm{n}^{\circ} 60$ de 19 de mayo de 1825, pp. 239 y 240; nº 61 de 21 de mayo de 1825 , p. 244.

28. Gaceta de Madrid, $\mathrm{n}^{\circ} 75$ de 23 de junio de 1825, pp. 301 y 302. 
acusados de celebrar reuniones sospechosas, que realizaban para preparar robos y no tanto con el objetivo de atacar al Gobierno real. Garbayo fue condenado a diez años de presidio en uno de África, Ochoa a ocho años también de presidio, Elizondo a dos y Hernández a seis, apercibiendo a todos los condenados que si reincidían serían castigados con mayor rigor. Garbayo, Ochoa y Hernández fueron enviados al presidio de Ceuta y Elizondo al de Jaca ${ }^{29}$.

En lo atinente a la comisión militar ejecutiva del reino de Galicia desde su instalación hasta el mes de julio falló varias causas por robo en cuadrilla, con el castigo para sus partícipes de penas que oscilaban entre la pena horca y presidio con distintos años de duración, según su responsabilidad; altercados públicos, sancionados con penas de arresto y apercibimiento; robos y vagancia, penados con trabajos en obras públicas o emisión de palabras subversivas, también castigados sus autores con trabajar en obras públicas. En total, se fallaron durante este periodo cuarenta y una causas, de las cuales en dieciocho acordó la comisión que se remitiesen los autos a los jueces de quienes dependían los reos y en dieciséis fueron castigados con penas correccionales de prisión por tratarse de hechos delictivos de escasa relevancia ${ }^{30}$.

Por su parte, la comisión de Navarra celebró varias sesiones los días 10 y 17 de agosto de 1824 para ver y sentenciar dos causas seguidas por los acontecimientos que tuvieron lugar en la ciudad de Sangüesa los días 10 de febrero, 12 y 13 de abril y 16 de mayo de ese año, en que hubo varios alborotos nocturnos que alteraron la tranquilidad pública, llegándose a robar en una casa y también porque algunos mozos cantaron canciones subversivas con vivas a la Constitución. Se dictó sentencia condenatoria contra Antonio Labari, Javier Aranguren, Miguel Erdozain, Francisco Sansol, Dionisio Quintana y Manuel Plano, naturales todos de dicha ciudad, castigados a la pena de diez años de presidio con retención en uno de los mayores. Estos cinco últimos fueron condenados en rebeldía por hallarse prófugos. Por su parte, también se condenó a Manuel Otir, del mismo pueblo, a la de cuatro años en el presidio de Ceuta, habiéndose tenido en consideración los servicios militares que prestó anteriormente; a Norberto Francés, Martín Colas y Ángel Machín a seis meses de presidio correccional en la ciudadela de Pamplona. Mientras Gabriel García, Venancio Iribarren, Miguel Esca, Antonio e Hipólito Novallas y Francisco Murillo fueron puestos en libertad, con apercibimiento y encargo a la justicia de su pueblo de que controlasen sus conductas y las opiniones que vertieran en adelante. Precisamente, el alcalde de la localidad, Joaquín Ibarra, fue sancionado con el pago de una multa de 50 ducados de plata por haber permitido que los reos de esta causa alterasen la tranquilidad pública.

Asimismo, en la sesión de 11 de agosto de 1824 se falló la causa seguida contra Santiago Domeño, Prudencio Otaño, Francisco Aguerri, Pablo Pérez y Francisco Arriaga, acusados de que, hallándose en la taberna de la localidad de Leache la tarde del 27 de mayo, gritó el primero viva la Constitución, de lo que resultó una

29. Diario balear, $\mathrm{n}^{\circ} 38$ de 8 de mayo de 1824 , p. 3 .

30. Gaceta de Madrid, $\mathrm{n}^{\circ} 87$ de 10 de julio de 1824 , p. 352 . 
pelea entre todos, con heridas a un paisano. Santiago Domeño fue condenado a dos años de presidio en la ciudadela de Pamplona; Martín Prudencio Otaño, Francisco Aguerri y Pablo Pérez a seis meses en el mismo presidio y Francisco Arriaga fue condenado en rebeldía a tres meses en ese destino. En el mismo día, también fue juzgado Hipólito Sanz, natural y residente en Marcilla, acusado de haber gritado viva la libertad el día 14 de marzo, habiendo sido condenado a seis meses de presidio en la referida ciudadela de Pamplona ${ }^{31}$.

Finalmente, la comisión de Navarra celebró consejo el 9 del mes de septiembre para juzgar a Juan Ángel Oses y consortes, vecinos de la villa de Peralta, acusados de haber perturbado la tranquilidad pública con alborotos y atropellos al alcalde de la misma, en varios días del mes de marzo, habiéndose pronunciado sentencia en que condenó a Juan Ángel Oses, Roque Oses y Miguel Quintana en cuatro años de presidio en uno de los mayores; a Prudencio Martínez, Blas Martínez, Anselmo Alonso y Ventura Basos en dos años de presidio. Mejor suerte corrieron Josefa Sanz de Arnedillo, Eugenia Martínez, Antonio Escudero, Francisco Troyas, Miguel Leza y Sebastián Pérez, todos puestos en libertad, para quienes sirvió de castigo el tiempo que habían sufrido en prisión. Asimismo, la comisión condenó a Juan Martín Zalba, vecino de Urroz, acusado de haber proferido algunas palabras alarmantes en la noche del 5 de agosto, a seis meses de presidio correccional en la ciudadela de Pamplona y a Fernando Garayoa, de la misma vecindad, a apercibimiento y amonestación por el alcalde del pueblo de su residencia para que en lo sucesivo no insultase a persona alguna ${ }^{32}$.

Respecto a las causas seguidas por la comisión militar de las provincias vascongadas nos encontramos la seguida contra los autores de un pasquín que se halló en la plaza de la iglesia vieja de la villa de Motrico y contra el regidor José Vicente de Echaniz, acusado de haber proferido la expresión viva negros. Fue absuelto el 19 de junio de 1824, por hallarse embriago en aquel lance, y haber acreditado su adhesión a la causa del rey en tiempos de la Constitución; Domingo de Anchia, subteniente del batallón de infantería número 47 del exejército constitucional, condenado a un año de castillo por habérsele hallado una cinta con el lema Constitución, Cortes, libertad o muerte; Francisco de Apraiz, teniente que fue de la milicia activa constitucional de Bilbao, condenado a la pena de un año de castillo por haber escrito una carta contra los realistas; Zacarías de Lejarza, Cirilo Lacunza, Manuel Abajo, Antonio Tapia, su mujer Nicolasa Landaluce y Baldomero Sarmiento, por interceptación de una carta procedente de Cádiz, que contenía noticias contra el Gobierno del rey y reuniones sospechosas, condenado el primero a ocho años de presidio en Ceuta y puestos en libertad los demás, con apercibimiento; Ramón de Gárate, condenado a seis años de obras públicas en Málaga por decir que era negro y quería serlo y que antes de mucho habian de estar los realistas bajo sus pies; Andrés García de Hoyo, condenado al pago de 20 ducados de multa por haber escrito una carta en sentido sospechoso; Andrés de Eguaguirre,

31. Diario balear, $\mathrm{n}^{\mathrm{o}} 77$ de 15 de septiembre de 1824, p. 4.

32. Gaceta de Madrid, $\mathrm{n}^{\circ} 124$ de 28 de septiembre de 1824, p. 498. 
coronel del regimiento de infantería de la Reina, por habérsele encontrado en su equipaje un cuadro de la Constitución en el acto de juramento del rey, un reloj con pinturas obscenas y varios periódicos de la época constitucional, fue condenado a cuatro años en la plaza de Ceuta, bajo la vigilancia de la autoridad militar de la misma y, por último, José Veraza, menor de 15 años, por haber proferido la voz de Viva la Constitución, fue absuelto por haberse probado que usó aquella expresión equivocadamente ${ }^{33}$.

En el sur peninsular, la actuación de las comisiones existentes también fue realmente destacable. Tal fue el supuesto de la de Murcia que falló durante los primeros meses, entre otras, las siguientes causas ${ }^{34}$ :

\begin{tabular}{|l|l|l|}
\hline Nombres de los procesados & \multicolumn{1}{|c|}{ Delitos } & \multicolumn{1}{|c|}{ Sentencias } \\
\hline $\begin{array}{l}\text { Juan Solana y Antonio } \\
\text { Ferreti }\end{array}$ & $\begin{array}{l}\text { Proferir expresiones } \\
\text { subversivas }\end{array}$ & Horca \\
\hline José Tomás Tapia & Quemar un retrato del rey & $\begin{array}{l}\text { Seis años de presidio en } \\
\text { Árica }\end{array}$ \\
\hline Juan Martínez Campero & $\begin{array}{l}\text { Proferir expresiones } \\
\text { alarmantes e indiscretas }\end{array}$ & $\begin{array}{l}\text { Quince años de prisión y a } \\
\text { que se vigilara su conducta }\end{array}$ \\
\hline $\begin{array}{l}\text { Juan Villagrasa, Francisco } \\
\text { Albaladejo, Braulio Campoy } \\
\text { yrancisco Carbonell }\end{array}$ & $\begin{array}{l}\text { Causar heridas a unos } \\
\text { franceses y gritar en público } \\
\text { Viva Riego }\end{array}$ & $\begin{array}{l}\text { El primero a un año de } \\
\text { destierro. Los demás, a } \\
\text { cuatro meses }\end{array}$ \\
\hline Joaquín González & Robo en despoblado & Horca \\
\hline $\begin{array}{l}\text { Antonio Fernández y José } \\
\text { Martínez }\end{array}$ & Alboroto & Puesto en libertad \\
\hline Manuel y José Mateos & $\begin{array}{l}\text { Perturbar la tranquilidad } \\
\text { pública }\end{array}$ & $\begin{array}{l}\text { El primero, puesto en } \\
\text { libertad. El segundo, enviado } \\
\text { a la justicia ordinaria por } \\
\text { poseer una arma prohibida }\end{array}$ \\
\hline José Pérez Cortés & Proferir palabras subversivas & $\begin{array}{l}\text { Tres años de presidio en el } \\
\text { de Alicante }\end{array}$ \\
\hline $\begin{array}{l}\text { José Martínez, Mariano } \\
\text { Molina y José Molina } \\
\text { Balibrera }\end{array}$ & $\begin{array}{l}\text { Poseer una proclama } \\
\text { sediciosa }\end{array}$ & $\begin{array}{l}\text { El primero, ocho años de } \\
\text { presidio en Ceuta. Los otros } \\
\text { dos, a la pena de horca en } \\
\text { rebeldía }\end{array}$ \\
\hline José Martínez Navarro & $\begin{array}{l}\text { Proferir expresiones } \\
\text { subversivas }\end{array}$ & $\begin{array}{l}\text { Multa de 30 pesos y } \\
\text { apercibimiento }\end{array}$ \\
\hline Mariano Raimundo Martínez & $\begin{array}{l}\text { Proferir expresiones } \\
\text { subversivas }\end{array}$ & $\begin{array}{l}\text { Cuatro meses de prisión en la } \\
\text { cárcel de Murcia }\end{array}$ \\
\hline Robo & $\begin{array}{l}\text { Un año de presidio } \\
\text { correccional en Valencia }\end{array}$ \\
\hline
\end{tabular}

33. Gaceta de Madrid, $\mathrm{n}^{\circ} 36$ de 24 de marzo de 1825, p. 144.

34. Gaceta de Madrid, $\mathrm{n}^{\circ} 147$ de 20 de noviembre de 1824, p. 592. 


\begin{tabular}{|c|c|c|}
\hline Nombres de los procesados & Delitos & Sentencias \\
\hline José Pane & $\begin{array}{l}\text { Participar en conversaciones } \\
\text { contra el rey }\end{array}$ & $\begin{array}{l}\text { Expatriación de los dominios } \\
\text { de España }\end{array}$ \\
\hline Juan Pedro Martínez Oliva & Poseer un papel subversivo & $\begin{array}{l}\text { Seis meses de destierro a } \\
\text { doce leguas de la villa de } \\
\text { Caravaca y al pago de costas }\end{array}$ \\
\hline Antonia Marco & $\begin{array}{l}\text { Proferir expresiones } \\
\text { subversivas }\end{array}$ & Dos años de reclusión \\
\hline Fernando Gil Miñano & $\begin{array}{l}\text { Provocar conmociones } \\
\text { populares y participar en } \\
\text { reuniones clandestinas }\end{array}$ & $\begin{array}{l}\text { Multa de doscientos ducados } \\
\text { a disposición del capitán } \\
\text { general y a que no pudiera } \\
\text { entrar en su pueblo durante } \\
\text { seis meses }\end{array}$ \\
\hline Diego Cuadrado Resalt & $\begin{array}{l}\text { Proferir expresiones } \\
\text { subversivas }\end{array}$ & Absuelto por falta de pruebas \\
\hline $\begin{array}{l}\text { Luis María Valcárcel, } \\
\text { Manuel Martín y Francisco } \\
\text { Ballesta }\end{array}$ & $\begin{array}{l}\text { Encubrir en su fuga al } \\
\text { alcalde mayor de la localidad } \\
\text { de Mula, Ignacio Francisco } \\
\text { Ayuso }\end{array}$ & $\begin{array}{l}\text { El primero, seis meses de } \\
\text { prisión en un castillo, en } \\
\text { atención a su condición de } \\
\text { militar y suspensión de } \\
\text { destino. Los otros dos, } \\
\text { puestos en libertad por } \\
\text { acuerdo con los ministros de } \\
\text { la Audiencia. }\end{array}$ \\
\hline
\end{tabular}

En el extremo occidental de la Península la comisión militar de Cádiz falló, desde su instalación el 20 de febrero de 1824 hasta el 31 de diciembre del mismo año, las causas seguidas contra ${ }^{35}$ :

\begin{tabular}{|l|l|l|}
\hline Nombres de los procesados & \multicolumn{1}{|c|}{ Delitos } & \multicolumn{1}{|c|}{ Sentencias } \\
\hline José Bellido & $\begin{array}{l}\text { Proferir expresiones } \\
\text { subversivas }\end{array}$ & $\begin{array}{l}\text { Un año de presidio } \\
\text { correccional }\end{array}$ \\
\hline José María Porterrios & Cantar coplas constitucionales & $\begin{array}{l}\text { Absuelto, al no probarse el } \\
\text { delito }\end{array}$ \\
\hline Andrés Negrete & Desafección al rey & Dos años de obras públicas \\
\hline $\begin{array}{l}\text { Ramón Pinillo y Manuel } \\
\text { Portela }\end{array}$ & $\begin{array}{l}\text { Proferir expresiones } \\
\text { subversivas en su trabajo }\end{array}$ & $\begin{array}{l}\text { Puestos en libertad al no } \\
\text { probarse el delito }\end{array}$ \\
\hline Juan Fernández & Gritar Viva la Constitución & Cinco años de presidio \\
\hline Santiago Fernández & Herir a un cabo & $\begin{array}{l}\text { Puesto en libertad por falta } \\
\text { de pruebas }\end{array}$ \\
\hline Serafín de Amores & $\begin{array}{l}\text { Herir a una mujer con un } \\
\text { cuchillo de uso prohibido }\end{array}$ & $\begin{array}{l}\text { Puesto en libertad por falta } \\
\text { de pruebas }\end{array}$ \\
\hline
\end{tabular}

35. Gaceta de Madrid, $\mathrm{n}^{\circ} 21$ de 17 de febrero de 1825, p. 83; nº 22 de 19 de febrero de 1825 , p. 88 . 


\begin{tabular}{|l|l|l|}
\hline Nombres de los procesados & \multicolumn{1}{|c|}{ Delitos } & \multicolumn{1}{c|}{ Sentencias } \\
\hline Pedro José Piloro & Poseer un cuchillo prohibido & Seis años de presidio \\
\hline Joaquín Vizcaya & Uso de arma prohibida & Dos años de destierro \\
\hline $\begin{array}{l}\text { Miguel Molina y Francisco } \\
\text { Lorenzo }\end{array}$ & $\begin{array}{l}\text { Promover una quimera para } \\
\text { desarmar a un soldado }\end{array}$ & $\begin{array}{l}\text { Puestos en libertad por no } \\
\text { probarse el delito }\end{array}$ \\
\hline Juan Antonio de la Canal & Matar a un soldado francés & Ocho años de presidio \\
\hline Ceferino Vega & $\begin{array}{l}\text { Amparar la deserción de un } \\
\text { soldado francés }\end{array}$ & $\begin{array}{l}\text { Puesto en libertad por falta } \\
\text { de pruebas }\end{array}$ \\
\hline
\end{tabular}

También en la zona meridional actuó la comisión de Málaga que, en poco más de un año, conoció de las causas seguidas contra ${ }^{36}$ :

\begin{tabular}{|l|l|l|}
\hline Identidad de los procesados & \multicolumn{1}{|c|}{ Delitos } & \multicolumn{1}{c|}{ Sentencias } \\
\hline $\begin{array}{l}\text { Francisco Alonso y José } \\
\text { Remén. El primero oficial } \\
\text { del Ministerio de Marina y el } \\
\text { segundo empleado de rentas }\end{array}$ & $\begin{array}{l}\text { Ser contrarios al Gobierno } \\
\text { real }\end{array}$ & $\begin{array}{l}\text { El primero, dos años de } \\
\text { destierro de Málaga y sus } \\
\text { arrabales. El segundo, seis } \\
\text { meses de igual pena }\end{array}$ \\
\hline $\begin{array}{l}\text { Diego Reyero, sargento } \\
\text { licenciado, natural de } \\
\text { Estepona, de 36 años }\end{array}$ & Infidencia & $\begin{array}{l}\text { Declarado inocente por no } \\
\text { resultar cargo alguno }\end{array}$ \\
\hline $\begin{array}{l}\text { Antonio Tudela, de San } \\
\text { Roque, vecino de Estepona, } \\
\text { de 44 años }\end{array}$ & Infidencia & $\begin{array}{l}\text { Declarado inocente por no } \\
\text { resultar cargo alguno }\end{array}$ \\
\hline $\begin{array}{l}\text { Antonio Aguilar, Juan Alejo } \\
\text { Campos, Juan Peña y Juan } \\
\text { Borrego, de Alozaina }\end{array}$ & Desafección al rey & $\begin{array}{l}\text { Declarados inocentes por } \\
\text { probados que eran hombres } \\
\text { pacíficos sin mezclarse en } \\
\text { asuntos políticos }\end{array}$ \\
\hline $\begin{array}{l}\text { Manuel Capilla, de Castilla } \\
\text { la Vieja, de 45 años }\end{array}$ & $\begin{array}{l}\text { Llevar cartas a los emigrados } \\
\text { a Gibraltar }\end{array}$ & $\begin{array}{l}\text { Absuelto por no probarse la } \\
\text { acusación }\end{array}$ \\
\hline $\begin{array}{l}\text { Francisco Pablo Domínguez, } \\
\text { capitán }\end{array}$ & Infidencia & $\begin{array}{l}\text { Absuelto por no resultar } \\
\text { cargo }\end{array}$ \\
\hline $\begin{array}{l}\text { Ignacio Sol, Josefa Puente, } \\
\text { Brígida Puente, Francisco } \\
\text { Krauser y Agustín Labale. } \\
\text { Los tres primeros de Málaga. } \\
\text { Los segundos de Alicante }\end{array}$ & $\begin{array}{l}\text { Tener correspondencia con } \\
\text { los revolucionarios }\end{array}$ & $\begin{array}{l}\text { Declarados inocentes por no } \\
\text { resultar cargo alguno }\end{array}$ \\
\hline
\end{tabular}

36. Gaceta de Madrid, $\mathrm{n}^{\mathrm{o}} 53$ de 3 de mayo de 1825, pp. 211 y $212 ; \mathrm{n}^{\circ} 54$ de 5 de mayo de 1825 , p. 215. Como aparece recogido en la tabla, entre los delitos de que conoció la comisión militar se hallaban los de infidencia. De esa forma, la jurisdicción militar recuperaba la competencia sobre los mismos que había perdido cuando el Consejo de Regencia de España e Indias ordenó, mediante decreto de 19 de junio de 1810, que fueran las salas del crimen de las Audiencias y demás jueces ordinarios quienes conocieran de dichas causas. Poco después, el 9 de octubre de ese año se informó por parte de la Comisión legislativa que el Consejo de Castilla presentase a las Cortes, a instancias del de Regencia, el reglamento e instrucción para sustanciar y fallar los delitos de infidencia. 


\begin{tabular}{|l|l|l|}
\hline Identidad de los procesados & \multicolumn{1}{|c|}{ Delitos } & \multicolumn{1}{c|}{ Sentencias } \\
\hline $\begin{array}{l}\text { José Iriza, teniente, } \\
\text { de Vergara, de 30 años }\end{array}$ & Infidencia & $\begin{array}{l}\text { Absuelto por no resultar } \\
\text { cargo }\end{array}$ \\
\hline $\begin{array}{l}\text { Manuel Espinosa y Blas } \\
\text { Barca, de Málaga y Míjar, de } \\
\text { 44 y 22 años. }\end{array}$ & $\begin{array}{l}\text { Proferir expresiones } \\
\text { subversivas }\end{array}$ & $\begin{array}{l}\text { Libres de acusación, } \\
\text { sirviéndoles de corrección el } \\
\text { arresto que llevaban }\end{array}$ \\
\hline $\begin{array}{l}\text { Antonio Alciator, } \\
\text { de Cerdeña, de 37 años }\end{array}$ & Infidencia & $\begin{array}{l}\text { Absuelto por no probarse la } \\
\text { acusación }\end{array}$ \\
\hline Fernando Boada, teniente & Infidencia & $\begin{array}{l}\text { Absuelto por no probarse la } \\
\text { acusación }\end{array}$ \\
\hline $\begin{array}{l}\text { Miguel de Nava, Juan de } \\
\text { Santos y Enrique Meller. } \\
\text { Capitán el primero y } \\
\text { tenientes los otros dos }\end{array}$ & $\begin{array}{l}\text { Celebrar reuniones } \\
\text { sospechosas con vecinos de } \\
\text { Archidona }\end{array}$ & $\begin{array}{l}\text { Declarados libres por no } \\
\text { probarse la acusación, pese a } \\
\text { que constasen sus } \\
\text { conductas liberales, por las } \\
\text { cuales fueron destinados a } \\
\text { diversos pueblos a más de } \\
\text { ocho leguas de Málaga }\end{array}$ \\
\hline
\end{tabular}

Las causas vistas y sentenciadas por la comisión de Granada desde el 25 de diciembre de 1824 hasta el 30 de abril de 1825 fueron las siguientes ${ }^{37}$ :

\begin{tabular}{|l|l|l|}
\hline Nombres de los procesados & \multicolumn{1}{|c|}{ Delitos } & \multicolumn{1}{c|}{ Sentencias } \\
\hline José de Molas & $\begin{array}{l}\text { Usar armas prohibidas y } \\
\text { sospechas de otros delitos }\end{array}$ & $\begin{array}{l}\text { Ocho años de presidio en el } \\
\text { de Melilla }\end{array}$ \\
\hline José Ballester & Tener papeles subversivos & $\begin{array}{l}\text { Dos años en el presidio de } \\
\text { Melilla }\end{array}$ \\
\hline Alfonso y Ventura Puida & Robo en despoblado & $\begin{array}{l}\text { Diez años de presidio en uno } \\
\text { de los de África. El primero } \\
\text { fue destinado al del Peñón. } \\
\text { El segundo al de Alhucemas }\end{array}$ \\
\hline $\begin{array}{l}\text { Ambrosio de Córdoba y José } \\
\text { Peralta }\end{array}$ & $\begin{array}{l}\text { Cantar canciones de la } \\
\text { Constitución }\end{array}$ & $\begin{array}{l}\text { Puestos en libertad, por falta } \\
\text { de prueba. El acusador, } \\
\text { Manuel Santisteban, } \\
\text { condenado a cuatro años de } \\
\text { presidio en el de Melilla }\end{array}$ \\
\hline Antonio García & $\begin{array}{l}\text { Proferir expresiones } \\
\text { subversivas }\end{array}$ & $\begin{array}{l}\text { Diez años de presidio. La } \\
\text { sentencia fue confirmada pro } \\
\text { la Real Chancillería y destinó } \\
\text { al reo al presidio del Peñón. }\end{array}$ \\
\hline Luis Trinidad López & $\begin{array}{l}\text { Proferir expresiones } \\
\text { insultantes y alarmantes } \\
\text { contra el rey }\end{array}$ & $\begin{array}{l}\text { Cuatro años de presidio en el } \\
\text { correccional de Málaga }\end{array}$ \\
\hline
\end{tabular}

37. Gaceta de Madrid, $\mathrm{n}^{\circ} 66$ de 2 de junio de 1825, pp. 265 y 266. 


\begin{tabular}{|l|l|l|}
\hline Nombres de los procesados & \multicolumn{1}{|c|}{ Delitos } & \multicolumn{1}{c|}{ Sentencias } \\
\hline $\begin{array}{l}\text { José Beltrán y José } \\
\text { Fernández }\end{array}$ & Robos en despoblado & $\begin{array}{l}\text { Seis años de presidio en el } \\
\text { de Ceuta }\end{array}$ \\
\hline Andrés Martínez & $\begin{array}{l}\text { Proferir expresiones } \\
\text { subversivas y alarmantes }\end{array}$ & $\begin{array}{l}\text { Ocho años de presidio en uno } \\
\text { de los menores de África }\end{array}$ \\
\hline $\begin{array}{l}\text { Onofre Coll y Jerónimo } \\
\text { Bernar }\end{array}$ & Robo en despoblado & $\begin{array}{l}\text { Ocho años de presidio en } \\
\text { Alhucemas y El Peñon, } \\
\text { respectivamente }\end{array}$ \\
\hline $\begin{array}{l}\text { Francisco González y José } \\
\text { Fernández }\end{array}$ & Robo en despoblado & $\begin{array}{l}\text { Seis años de obras públicas } \\
\text { en Málaga }\end{array}$ \\
\hline Juan Lagos & $\begin{array}{l}\text { Resistencia a la policía y } \\
\text { proferir palabras subversivas }\end{array}$ & $\begin{array}{l}\text { Dos años de presidio en uno } \\
\text { de los de África. Fue } \\
\text { destinado al de Melilla }\end{array}$ \\
\hline Bernardo López & $\begin{array}{l}\text { Compra de unas yeguas } \\
\text { robadas }\end{array}$ & $\begin{array}{l}\text { Pérdida del dinero que pagó } \\
\text { y dos meses de prisión }\end{array}$ \\
\hline Francisco García & $\begin{array}{l}\text { Proferir palabras subversivas } \\
\text { contra el rey }\end{array}$ & $\begin{array}{l}\text { Cuatro años de presidio en el } \\
\text { de Ceuta }\end{array}$ \\
\hline
\end{tabular}

Además de estas causas, se vieron, según informó la propia comisión, otras muchas en que fueron absueltos los acusados ${ }^{38}$.

Asimismo, esta comisión militar intervino en 87 causas formadas contra varios sujetos y por diferentes delitos desde el 30 de abril hasta el 23 de julio de 1825, 80 de las cuales o bien fueron sobreseídas o absueltos los reos por no aparecer cargo alguno contra ellos.

Las siete restantes que se fallaron fueron las siguientes ${ }^{39}$ :

\begin{tabular}{|l|l|l|}
\hline Nombres de los procesados & \multicolumn{1}{|c|}{ Delitos } & \multicolumn{1}{c|}{ Sentencias } \\
\hline $\begin{array}{l}\text { Juan Sánchez, María } \\
\text { Rodríguez }\end{array}$ & Robo en despoblado & $\begin{array}{l}\text { El primero a seis años de } \\
\text { presidio en uno de los de } \\
\text { África. La segunda a dos } \\
\text { años de reclusión en el } \\
\text { hospicio de Granada }\end{array}$ \\
\hline $\begin{array}{l}\text { José de Reyes y Pedro } \\
\text { García Cano }\end{array}$ & $\begin{array}{l}\text { Proferir palabras subversivas } \\
\text { y alarmantes contra el } \\
\text { Gobierno }\end{array}$ & Diez años de presidio \\
\hline Domingo Montero & $\begin{array}{l}\text { Robo y deserción del } \\
\text { presidio de Málaga }\end{array}$ & $\begin{array}{l}\text { Cuatro años en el mismo } \\
\text { presidio }\end{array}$ \\
\hline $\begin{array}{l}\text { Juan Pedro Salcedo y } \\
\text { Manuel Sánchez }\end{array}$ & $\begin{array}{l}\text { Deserción y robo, } \\
\text { respectivamente }\end{array}$ & $\begin{array}{l}\text { El primero, cuatro años de } \\
\text { presidio. El segundo a uno. }\end{array}$ \\
\hline
\end{tabular}

38. Gaceta de Madrid, $\mathrm{n}^{\circ} 66$ de 2 de junio de 1825 , pp. 265 y 266.

39. Gaceta de Madrid, $\mathrm{n}^{\circ} 94$ de 6 de agosto de 1825, p. 378. 


\begin{tabular}{|l|l|l|}
\hline Nombres de los procesados & \multicolumn{1}{|c|}{ Delitos } & \multicolumn{1}{|c|}{ Sentencias } \\
\hline Manuel de Cáceres & $\begin{array}{l}\text { Resistencia a una partida de } \\
\text { voluntarios realistas en el } \\
\text { acto de prenderlo y tenencia } \\
\text { de un cuchillo prohibido }\end{array}$ & Diez años de presidio \\
\hline Nicolás Olaya & Vagancia & $\begin{array}{l}\text { Dos años de destierro del } \\
\text { pueblo donde había residido } \\
\text { últimamente }\end{array}$ \\
\hline $\begin{array}{l}\text { Manuel de Martos, Andrés } \\
\text { de Rojas y Andrés Ortiz }\end{array}$ & Robo en despoblado & $\begin{array}{l}\text { El primero y el segundo, diez } \\
\text { años de presido. El tercero, } \\
\text { ocho en uno de los de África }\end{array}$ \\
\hline
\end{tabular}

Tras poco más de año y medio funcionando, por real cédula de 4 de agosto de 1825 se mandó que cesaran en todo el Reino las comisiones militares ejecutivas y permanentes. Se reconoció que, gracias a la eficacia con que actuaron dichas comisiones, se habían reducido considerablemente los delitos que dieron motivo a su creación, pero que, en la medida que en la mayor parte de los pueblos se encontraban plenamente operativos los cuerpos de voluntarios realistas para perseguir a los delincuentes y que ya no había que temer por las actuaciones de los revolucionarios, sin olvidar lo dispuesto en el decreto del propio Fernando VII de 26 de enero de 1816, donde se establecía que las causas criminales no fuesen juzgadas por comisiones, sino por la jurisdicción ordinaria, con la excepción de las de aquellos que gozasen de fuero privilegiado, se dispuso que todas las causas pendientes se pasasen a los jueces y tribunales respectivos para que las sustanciaran, concluyeran y determinaran con arreglo a Derecho ${ }^{40}$.

De la misma forma que aconteció en otras comisiones, a principios de agosto de 1825 quedaban aún pendientes de fallo 157 causas en la de Castilla la Nueva y que fueron remitidas, en cumplimiento de lo dispuesto en la real cédula, a la Sala de Alcaldes de Casa y Corte. Dicho órgano adjudicó los siguientes destinos a los individuos procesados: 8 azotados y enviados a presidio; 60 condenados a presidios mayores; 22 condenados a presidio correccional; 105 absueltos libremente; 191 absueltos y condenados en costas; 238 puestos en libertad; 25 desterrados; 1 destinado a castillo y 1 mujer destinada a galera. Todo ello representó un total de 651 procesados $^{41}$.

40. Real cédula de 4 de agosto de 1825, Imprenta Real, Madrid, 1825; Mercurio de España, agosto de 1825, pp. 97-99; Diario de avisos de Madrid, n 132 de 10 de agosto de 1825, pp. 550-551. González López 1986, p. 93 destaca la influencia que en esta decisión real tuvieron hombres de ideas moderadas como el ministro Cea Bermúdez o Luis Fernández de Córdova. Según los datos facilitados por Pegenaute 1974, durante este periodo las comisiones militares condenaron a un total de 1094 personas. De entre ellas, algo más de la mitad por delitos políticos y las demás por comunes, siendo castigadas a muerte 132. Ballbé 1983, p. 89 critica a este último autor por afirmar que el número total de condenados era de poca importancia en relación a la población española. Sostiene su reproche en que Pegenaute no ofrece el número total de procesados, incluyendo los absueltos, que sufrieron prisión preventiva.

41. Gaceta de Madrid, $\mathrm{n}^{\circ} 134$ de 5 de noviembre de 1825, p. 535. 
Entre las causas que fueron remitidas a la Sala de Alcaldes se encontraba la seguida contra Cayetano Terol y Miguel Salvador por complicidad en los robos cometidos por José Martín, alías “El pájaro de Miraflores”. Además, Terol y Salvador fueron acusados de varias muertes en Rascafría, por lo que la comisión de Castilla la Nueva inició procesamiento en abril de $1825^{42}$. Otra fue la seguida contra Blas Díaz, alias “el Tuerto de Perdernoso o Bolín”, y consortes por robos en cuadrilla y despoblado con fuerza armada. La comisión remitió la causa a la Sala de Alcaldes, que condenó a muerte a Díaz, siendo ejecutado en $1826^{43}$.

Igualmente, se remitieron los autos en el pleito de Viviano Porrás, marqués de Chiloeches y la Celada y comandante del Tercio de voluntarios realistas de infantería de Espinosa de los Monteros contra Sandalio Arce, escribano de número de esa localidad y sargento del citado tercio y José María López, su criado, por acusarles de haber custodiado en su casa una lápida de la Constitución y sembrar discordias entre los realistas. La causa se inició el 18 de marzo de 1825, remitiéndose los autos, tras la extinción de la comisión, al gobernador y alcaldes del crimen de la Real Chancillería de Valladolid. Por auto de 15 de noviembre de 1825 se mandó que se enviasen a la justicia de Espinosa de los Monteros para que determinase la causa. La sentencia se dictó el 18 de mayo de 1826 por Leonardo Diego Madrazo, alcalde ordinario de la localidad, y al día siguiente remitió los autos a la Sala de lo Criminal. Finalmente, el gobernador y los alcaldes del crimen dictaron el auto definitivo el 13 de julio de $1826^{44}$.

\section{SEGUNDA FASE: Del 18 DE MARZO}

\section{DE 1831 AL 29 DE JULIO DE 1834}

Aunque, como hemos dicho, en agosto de 1825 se mandó cesar las comisiones militares, ciertos acontecimientos, que perturbaron gravemente el orden público, obligaron a su restablecimiento 18 de marzo de 1831, tanto en Madrid como en las capitales de provincia que los respectivos capitanes generales juzgasen oportu$\mathrm{no}^{45}$. Todas ellas estarían compuestas por un presidente de la clase de mariscal de campo o de la de brigadier; de un asesor, que en Madrid sería un alcalde de casa y corte a elección del capitán general de Castilla la Nueva y en las provincias el ministro de Chancillería o Audiencia que nombrase el presidente de la misma y de seis vocales de la clase de brigadieres o tenientes coroneles, proponiéndolos el capitán general para la aprobación real. El asesor ocupaba el asiento inmediato al presidente en todas las comisiones. En cada una de las mismas, habría los fiscales y secretarios que, según el número de causas, estimase necesarios el presidente,

42. Archivo Histórico Nacional, CONSEJOS, 8942, exp. 4.

43. Archivo Histórico Nacional, CONSEJOS, 8935, exp. 1.

44. Archivo de la Real Chancillería de Valladolid, SALAS DE LO CRIMINAL, caja 7,5.

45. Ballbé 1983, p. 90. 
quien los proponía al capitán general para su nombramiento, eligiéndolos de la clase de capitanes.

Quedaban sujetos al juicio de estas comisiones militares ejecutivas y permanentes quienes, desde el día de su instalación, cometiesen los delitos indicados en el decreto de 1 de octubre de 1830, siendo del cargo del superintendente general de policía remitir a los capitanes generales, donde aquéllas se establecieran, las listas tratadas en el artículo 6 de dicho decreto para la aplicación a los reos de la pena allí establecida y de las demás que merecieran por sus hechos posteriores $^{46}$. Igualmente, quedaban sujetos al juicio de las mismas comisiones los que se declarasen con armas o actos enemigos de los derechos del rey o partidarios de la Constitución; los que escribieran papeles o pasquines dirigidos a los mismos fines, los que hablasen contra la soberanía real, los que sedujeran o intentasen con palabras, promesas o dádivas seducir a otros para retraerlos de su fidelidad al monarca o para formar alguna partida que tuviese como fin ayudar a los planes de una facción rebelde y quienes difundieran noticias relativas a las fuerzas de la misma facción o de cualquier otra cosa de igual naturaleza, que pudiera inspirar temor entre los vecinos.

Las causas se debían sustanciar en el término más corto posible, bajo la responsabilidad del presidente, vocales y fiscal, debiendo omitirse la evacuación de citas inconducentes y también la fórmula de careos, salvo que los pidiera el defensor. Las dudas que surgieran durante la formación de los procesos se resolvían por el asesor de la comisión, a quien acudían los fiscales por conducto de los presidentes $y$, cuando fuese necesario evacuar diligencias en otras provincias, presentaban a éstos sus oficios, acompañados de los documentos que correspondía, para que se remitieran a los capitanes generales respectivos.

Si eran muchos los reos procesados por un mismo delito, se formaban ramos separados, previo dictamen del asesor, para abreviar de este modo la sustanciación y conseguir el pronto castigo o libertad de los acusados. Finalizadas las causas, se entregaban al presidente de la comisión para que las pasase al asesor. Hay que recordar que los asesores no tenían voto para el fallo, con arreglo a lo establecido en los procesos militares, pero ilustraban a los vocales antes de la votación.

Pronunciada sentencia se remitía con el proceso al capitán general de la provincia, que la pasaba al auditor de guerra para que la examinase con toda preferencia. Si de esta revisión resultaba que la hallaba arreglada, el capitán general disponía que se ejecutase sin dilación, pero si, por el contrario, el auditor hallase motivo fundado que ofrecía duda o exigía consulta, el capitán general, como presidente de la Chancillería o Audiencia, nombraba tres ministros de ella para que

46. Dicho art. 6 del Real decreto de 1 de octubre de 1830, Gaceta de Madrid, ${ }^{\circ} 119$ de 2 de octubre de 1830 señalaba lo siguiente: "el superintendente general de policía formará a la mayor brevedad la lista nominal de los emigrados contumaces contra quienes haya recaído sentencia condenatoria de cualquier tribunal del reino por crímenes revolucionarios y con nota de su filiación, tan expresiva como pueda hacerse, se comunicará a las autoridades civiles y militares de las fronteras de tierra y puestos de mar para que vigilen sobre su introducción en el reino y en cualquier punto en que sea aprehendido, aun cuando vengan desarmados, se les impondrá la pena a que se les haya condenado". 
viesen la causa y con su dictamen decidía o consultaba al Consejo Supremo de Guerra, extendiendo los fundamentos de su duda.

En Castilla la Nueva pasaba el capitán general oficio al gobernador o decano del Consejo Real, para que, nombrados por éste tres ministros de la Sala de alcaldes de casa y corte, decidiera con el dictamen de éstos los procesos que ofrecían duda, según queda dicho. Los procesos contra reos ausentes los seguía la comisión militar llamándolos por edictos y pregones con tres días de término cada uno $\mathrm{y}$, si después eran aprehendidos los reos o se presentaban, se observaba lo que en cuanto a su audiencia estaba previsto en las leyes.

Las justicias ordinarias y las militares continuaban conociendo de las causas que hubiesen incoado sobre los mismos delitos hasta la instalación de las comisiones militares y las sustanciaban y determinaban a la mayor brevedad con arreglo a las leyes y reales decretos, pero si, desde que aquéllas se instalasen tenían noticia de haberse cometido alguno de los expresados delitos, formaban sumaria para acreditar el hecho y la remitían a la respectiva comisión, practicando igual entrega la policía con las diligencias instruidas ${ }^{47}$.

Tan solo un día después, por real decreto de 19 de marzo de 1831, se mandó que la comisión militar ejecutiva y permanente de Castilla la Nueva conociera de los delitos de robo. Se indicó que, desde hacía tiempo, se habían producido desórdenes y robos que amenazaban la tranquilidad pública por maquinaciones de los revolucionarios y se había atacado la seguridad de los bienes y personas de los vecinos de la corte. Por todo ello y teniendo en consideración los efectivos resultados conseguidos con la puesta en práctica de la real orden de 20 de enero de 1824, por la brevedad con que instruía la comisión militar los procesos y fijaba la condena de los reos, se mandó que la comisión militar actuase contra todos los que, desde el día en que la misma se estableciera, cometiesen en la Corte y su rastro el delito de robo o los actos preparatorios y dirigidos a él, tales como amenazar a las personas o violentar puertas, ventanas o cerraduras, ya se ejecutasen de día o de noche y con independencia de que los delincuentes fuesen aprehendidos por la tropa, ministros de justicia, cualquier otra autoridad o persona.

Las causas que sobre tales delitos formase la comisión militar se debían instruir y sustanciar conforme al modo y trámites recogidos en el anteriormente citado decreto del día 18. Asimismo, para la justificación del delito se había de observar lo mandado en la pragmática de 23 de febrero de $1734^{48}$ y para la graduación e imposición de las penas se estimaban robos cualificados, susceptibles de ser castigados con la pena capital, los perpetrados con violencia, escalamiento o rompimiento de pared, tejado o puerta principal, fractura de puerta interior, arca, cofre, escritorio o papelera con llave falsa o ganzúa. Para el resto de hurtos como los domésticos

47. Real decreto de 18 de marzo de 1831; Gaceta de Madrid, $\mathrm{n}^{\circ} 37$ de 22 de marzo de 1831, pp. 141 y 142; Nieva 1832, tomo XVI, pp. 127-132. A la reinstauración de las comisiones se refieren Morales Ruiz 2003, p. 91; Pérez Núñez 2004, p. 649.

48. Novísima Recopilación XII,14,3. En esta norma se estableció que "para la justificación del crimen de hurto e imponer la pena ordinaria al reo, baste la de ser probado por un solo testigo idóneo, aunque sea el robado, o cómplice confeso de si". 
o aquellos en que no concurrían las anteriores circunstancias, se imponían penas $\operatorname{arbitrarias}^{49}$, con independencia de que la cantidad sustraída sobrepasase los 50 pesos, según lo prevenido en la real cédula de 4 de agosto de 1825 , que seguía vigente en este punto. Finalmente, la Sala de Alcaldes, como los demás tribunales de la Corte, continuarían entendiendo y conociendo de las causas ya incoadas sobre delitos de robo, al margen de que los reos estuviesen presos o prófugos, con la indicación de que debían hacerlo con la mayor brevedad posible ${ }^{50}$.

Conforme a todo ello se produjo el restablecimiento de la comisión militar ejecutiva y permanente de Castilla la Nueva, que estuvo formada en los inicios de esta segunda etapa por el brigadier Francisco Haro, como presidente; José Zorrilla y Caballero, como asesor y los brigadieres Francisco Casasola y Francisco Mallent y Navarro, los coroneles Esteban Miró y Nicolás Durán y los tenientes coroneles José Rivas e Ignacio de la Villa como vocales ${ }^{51}$.

Al igual que en la capital, también en otras ciudades comenzaron a funcionar de nuevo las comisiones militares como fue el caso de la de Granada, que en agosto de 1831 condenó a pena de muerte en garrote a Manuel López Gil, acusado de salteador de caminos y otros graves crímenes, en unión de la banda de los llamados Botijas. Pocos días después fueron condenados por los mismos hechos y a idéntica pena Diego Barnedo, Juan Isidro Sánchez, Manuel de Martos, Juan Manuel de Teba, José González, José Cobo Ortega, José Prieto y Juan de Dios López, mientras que Francisco de Sales Yegüas y Rafael de Lara, lo fueron a diez años de presidio con retención en África ${ }^{52}$.

Aunque, quizá, una de las más llamativas fue la causa instruida en la misma comisión granadina contra Juan Almansa, menor, vecino de Linares, acusado de varios robos en despoblado y del asesinato cometido en la persona de Rodrigo Sanjurjo, corregidor de Mancha Real. Fue condenado el 7 de febrero de 1832 a la pena de ser arrastrado y muerto en garrote vil, cortándole después la cabeza y la mano ${ }^{53}$, que sería colocada aquélla a doscientos pasos del pueblo de su vecindad en el camino más público y ésta a igual distancia de la villa de Mancha Real. La

49. Sobre esta cuestión, no debemos olvidar que durante el Antiguo Régimen los jueces gozaron de un amplio margen de discrecionalidad a la hora de dictar sentencia, aumentando o disminuyendo la pena fijada por la ley, según ellos lo creyesen conveniente. Arbitrio judicial que venía reconocido por vía legal desde el siglo XIII en las Partidas (VII,10,15), cuando o no había norma que dispusiera la pena aplicable al delito o bien cuando, pese a existir, los jueces usaban de esta facultad para amoldar la ley al caso del que estaban conociendo.

50. Real decreto de 20 de marzo de 1831; Gaceta de Madrid, $\mathrm{n}^{\circ} 38$ de 24 de marzo de 1831, p. 147; Nieva 1832, tomo XVI, pp. 132-134.

51. Gaceta de Madrid, $\mathrm{n}^{\circ} 44$ de 7 de abril de 1831, p. 174.

52. Diario balear de 21 de octubre de 1831, p. 4.

53. Esta pena fue establecida en una pragmática de Felipe IV de 15 de junio de 1663 . Respecto al macabro acto del descuartizamiento del cadáver de un delincuente fue descrito con gran minuciosidad por Gutiérrez 1818, tomo I, p. 314, quien afirma que "quando se manda descuartizar los cadáveres de los ajusticiados para poner los quartos en los caminos, concurren también por la noche los individuos de las cofradias y entregan el cadáver al ejecutor de la justicia, quien le pone en un carro, y acompañado de alguaciles y del escribano oficial de la sala, le conduce a los parages donde han de ponerse los quartos, de todo lo qual pone el escribano testimonio, de que se da cuenta a la sala y que se une a la causa. Además, los hermanos de la cofradía de la misericordia se ejercitan, entre otras obras de 
sentencia fue ejecutada el 23 del mismo mes y es una muestra irrefutable del rigor con que se seguían aplicando en España a esas alturas del siglo XIX las anacrónicas penas del Antiguo Régimen.

Cuatro días después, falló la causa instruida contra Juan Zapata, vecino de Almería, acusado también de robos en despoblado y otros excesos. Al igual que el anterior, fue condenado a la pena de muerte en garrote, que sufrió en el mismo día $23^{54}$. Los mismos delitos perpetraron Tomás de Gámez, alias "el Frailete", vecino de Linares, y Manuel Ortega, de Cabra del Santo Cristo. En atención a sus circunstancias personales fueron condenados a diez años de presidio en el Peñón y en el de Alhucemas, respectivamente, y a la pena de doscientos azotes para cada uno, que sufrieron el día 12 de mayo último; Juan Rodríguez Díaz, alias el Dragón, vecino de Osuna, condenado a la pena de muerte en garrote vil, ejecutada el día 18; Francisco Rodríguez, José Jiménez, José Cozano y Francisco Sanz Marín, los dos primeros vecinos de Luque, el tercero de Cuevas Bajas y el cuarto de Cartama, condenados a la pena de muerte en garrote vil, que sufrieron el 24 por el delito de asesinato Jiménez y Cozano y de robos en cuadrilla y despoblado y, por último, Pedro Granados, vecino de Albox, acusado de robo en despoblado, fue condenado a la pena de muerte en garrote vil ${ }^{55}$.

Con la muerte de Fernando VII y el consabido inicio de la primera guerra carlista, la reina regente no tuvo más remedio que realizar concesiones a los liberales para que éstos apoyasen la causa de su hija Isabel. Sin lugar a dudas, entre aquéllas debió hallarse la supresión de las comisiones militares ejecutivas y permanentes, que, como hemos venido insistiendo en estas líneas, fueron órganos represores que actuaron de forma muy activa contra los sujetos partidarios de esa ideología.

Así debió ser. Antes de que se cumpliera el primer aniversario del fallecimiento del monarca se promulgó un real decreto por el que se procedía a restituir a la jurisdicción ordinaria las atribuciones que, conforme a las leyes del reino, le competían y, por consiguiente, a cesar las comisiones militares en todas las provincias. Eso supuso que las causas pendientes en ellas pasaran a las audiencias respectivas, para la ulterior sustanciación y consiguiente fallo. A partir de la fecha del decreto, las causas que ocurriesen sobre delitos de que tradicionalmente habían conocido las indicadas comisiones se instruirían por alcaldes o corregidores letrados del partido, dando cuenta cada cuatro días al Tribunal Superior de lo que en ellas se iba produciendo. Para la rápida sustanciación de estas causas se habilitaron incluso los días feriados. Pronunciada la sentencia y antes de su notificación, se elevaba en consulta al Alto Tribunal con la causa original y, en su vista, la sala a quien correspondiese aprobaba o rectificaba el fallo del inferior para hacer ejecutivo lo que declarase ${ }^{56}$.

caridad, en recoger los quartos de los ajusticiados puestos en los caminos para darles sepultura en el día que está destinado".

54. Gaceta de Madrid, $\mathrm{n}^{\mathrm{o}} 29$ de 8 de marzo de 1832, p. 118.

55. Gaceta de Madrid, $\mathrm{n}^{\circ} 78$ de 30 de junio de 1832, p. 324.

56. Real decreto de 29 de julio de 1834 . 
Conforme a esto último se actuó no sin reticencias, por ejemplo, en el pleito seguido por Dionisio Enriquez, alcalde ordinario de Palacios de Campos (Valladolid) contra Ambrosio Nieto, labrador, excomandante de voluntarios realistas, acusado de decir que no quería pertenecer a la milicia urbana en el acto de alistamiento de la misma que tuvo lugar el 8 de mayo de 1834 en la Casa Consistorial, añadiendo con furia que sólo por la fuerza se alistaría. Por auto del gobernador y alcaldes del crimen de 21 de julio de 1834 se mandó que el alcalde mayor de la ciudad de Medina del Campo reclamase al presidente de la comisión militar ejecutiva la causa en cuestión. El presidente, marqués de Novares, contestó el 31 de julio al alcalde mayor que, siendo indispensable el conocimiento de la causa a la comisión, de ningún modo podía acceder a la remisión solicitada y le recordó que la comisión había dado providencia el 13 de julio por la que se sobreseía la causa al no hallar méritos para su continuación. Pocos días después y sólo cuando la comisión quedó extinguida, se remitió la causa a la Sala del Crimen de la Real Audiencia de Valladolid ${ }^{57}$.

De otro lado, pese al claro tenor del decreto de 29 de julio de 1834, parece que siguió generando dudas el alcance de su aplicación. Así, el capitán general de Extremadura consultó si debían cesar o no las comisiones militares en el conocimiento de las causas que tenían a su cargo, ya que el artículo 247 de la Constitución establecía que ningún español podía ser juzgado en causas civiles y criminales por ninguna comisión, sino por el tribunal competente determinado con anterioridad por la ley ${ }^{58}$. La reina, conformándose con el dictamen del tribunal especial de guerra y marina, contestó en enero de 1837 que la existencia de las enunciadas comisiones era incompatible con la ley vigente a no hallarse declarada una provincia en estado de sitio $^{59}$.

Concluimos estas líneas indicando que este último mandato de la reina no fue acatado con la extensión que sería de esperar. Sólo así se comprende que, a finales de ese mismo año, llegaran noticias a la Corte de que en algunas provincias seguían existiendo consejos que se titulaban ordinarios cuando en realidad eran permanentes, sin que fueran éstos los que la ley tenía previstos para juzgar los delitos en que la jurisdicción militar debía entender cuando las provincias no se hallaban en estado de guerra. Por todo ello, se volvió a ordenar que cesasen inmediatamente y que, en su caso, fuesen sustituidos por los que marcaban las ordenanzas, cuyos vocales, exceptuando el presidente, debían ser de la clase de capitanes ${ }^{60}$.

57. Archivo de la Real Chancilleria de Valladolid, SALAS DE LO CRIMINAL, caja 300, 2, fols. $39 \mathrm{v}-41 \mathrm{v}$.

58. Pino Abad (2011), p. 420.

59. Real orden de 12 de enero de 1837.

60. Real decreto de 31 de diciembre de 1837. De forma similar se redactó la real orden de 29 de septiembre de 1839 , lo que demuestra que la supresión definitiva aún estaba lejos de producirse, justo seis años después del fallecimiento de Fernando VII. Colección de las leyes, decretos y declaraciones de las Cortes y de los reales decretos, órdenes, resoluciones y reglamentos generales expedidos por las Secretarías del Despacho desde el $1^{\circ}$ de enero hasta el fin de diciembre de 1839, tomo XXV, p. 466; Martín Carramolino 1840, p. 13; Vallecillo 1852, pp. 697 y 698; Bacardi, 1857, p. 240. 


\section{BIBLIOGRAFÍA}

Artola, Miguel (1978), Antiguo Régimen y revolución liberal, Barcelona.

Artola, Miguel (1981), La burguesía revolucionaria (1808-1874), Madrid.

Bacardi, Alejandro de (1848), Nuevo colón o sea tratado del Derecho militar de España, Barcelona.

Ballbé, Manuel (1983), Orden público y militarismo en la España constitucional (1812-1983), Madrid.

Barroso González, Jorge Luis (2014), “La perspectiva penal de la resocialización: su comportamiento histórico en Cuba", Revista Caribeña de Ciencias Sociales, $\mathrm{n}^{\circ} 3$.

Carr, Raymond (1984), España 1808-1975, Barcelona.

Duque de Castro Terreño (1829), Cuaderno de las leyes y agravios reparados a suplicación de los tres estados del Reino de Navarra, Imprenta de Longas, Pamplona.

Fiestas Loza, Alicia (1994), Los delitos políticos, Salamanca.

Garriga, Carlos y Lorente, Marta (1998), "El modelo constitucional gaditano", en Il modelo costituzionale inglese e a sua recezione nell'area mediterranea tra la fine del 700 e la prima metá dell'800, Milano.

González López, Emilio (1986), Luis López Ballesteros, 1782-1853. Ministro de Hacienda de Fernando VII, Fundación Pedro Barrié de la Maza, Universidad de Berkeley.

Gutiérrez, José Marcos (1818), Práctica criminal de España, Madrid.

Herr, Richard (1977), Ensayo histórico de la España contemporánea, Jaén.

Hidalgo, Dionisio (1973), Diccionario general de bibliografía española, Georg Olms Verlag, New York.

Mariana, Juan de (1840), Historia general de España, aumentada con las tablas del autor y adicionada con una narración de sucesos desde 1600 hasta 1833 o sea hasta la muerte del rey Don Fernando VII, tomo X, Imprenta de Francisco Oliva, Barcelona.

Martín Carramolino, Juan (1840), Suplemento del año de 1839 al método actual de la sustanciación civil y criminal en la jurisdicción real ordinaria, Imprenta de León Amarita, Madrid.

Morales Ruiz, Juan José (2003), "Fernando VII y la masonería española”, Hispania Nova. Revista de Historia Contemporánea, 3, pp. 75-92.

Nieva, José María (1832), Decretos del rey nuestro señor Don Fernando VII y reales órdenes, resoluciones y reglamentos generales expedidos por las Secretarías del Despacho Universal y Consejos de S. M. desde $1^{\circ}$ de enero hasta fin de diciembre de 1831, Imprenta Real, Madrid.

Ortego Gil, Pedro (2015), Entre jueces y reos. Las postrimerías del Derecho penal absolutista, Madrid.

Pegenaute Garde, Pedro (1974), Represión política en el reinado de Fernando VII. Las comisiones militares (1824-1825), Pamplona. 
Pérez Núñez, Javier (2004), "El primer Ministerio de Fomento y sus delegados, 1832-1834. Otra perspectiva desde el caso de Madrid”, Hispania 64, no 217, pp. 637-688.

Peset Reig, Mariano y José (1967), "Legislación contra liberales en los comienzos de la década absolutista (1823-1825)", Anuario de Historia del Derecho Español, pp. 437-485.

Pino Abad, Miguel (2011), “Apuntes sobre las garantías del proceso penal en las Cortes de Cádiz”, Anuario de Historia del Derecho Español, pp. 409-436.

Revuelta González, Manuel (1973), Política religiosa de los liberales en el siglo $X I X$, Madrid.

Vallecillo, Antonio (1852), Ordenanzas de S. M. para el régimen, disciplina, subordinación y servicio de sus Ejércitos, tomo III, Madrid. 